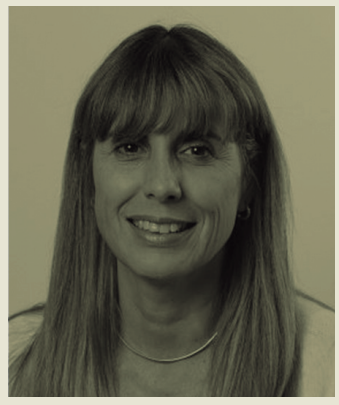

\title{
GERAÇÃO Y, COMO TRABALHAR COM ELA?
}

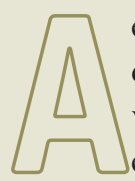

entrada da chamada geração Y no mercado de trabalho tem trazido um interesse renovado na questão das diferenças geracionais e o impacto que isso pode causar na gestão das organizações. Esse interesse parece estar fundamentado na crença de que os jovens nascidos aproximadamente entre 1978 e 1990 não são apenas diferentes quando comparados aos mais velhos, mas também são muito mais difíceis de serem "decifrados" e, portanto, adequadamente tratados no ambiente profissional.

As características atribuídas a esse público são inúmeras. Em relação ao trabalho, as mais relevantes têm sido: a habilidade de fazer várias coisas ao mesmo tempo; a capacidade de absorção de um grande número de informações; a rapidez de raciocínio; a vontade de aprender; a urgência de crescer rapidamente em termos profissionais; e uma forte orientação para os seus próprios valores. Portanto, quando colocados em situações que não conseguem satisfazer suas expectativas, ou seja, quando a atividade é monótona ou tenham que lidar com valores distintos dos seus, eles não veem perspectivas de avanço na carreira e a movimentação é inevitável, o que os faz escolher outra organização. E, daí, a característica de falta de comprometimento também lhes é atribuída. Mas vale indagar: seriam essas expectativas tão diferentes? Estão esses jovens querendo demais do trabalho?

Podemos pensar que talvez os "Ys" estejam apenas procurando uma atividade que faça mais sentido para eles, e, no fim das contas, o que buscam não está muito distante daquilo que propõem diversos teóricos, dizendo que um trabalho tem sentido quando proporciona o aprendizado; propicia o crescimento profissional como um todo, o que não significa apenas promoções; contém tarefas variadas, que sejam interessantes e tragam prazer; gera reconhecimento, fazendo a pessoa se sentir bem consigo; oferece segurança e remuneração justa; e, talvez o mais importante, quando o trabalho em si tem sentido para a pessoa que o desempenha, permitindo que um futuro profissional desejável seja delineado.

Pode ser que os "Ys" não estejam encontrando essas possibilidades em muitas organizações, as quais ainda têm dificuldades de inovar em seus processos de trabalho. Portanto, aqui fica um alerta para as empresas com alto turnover desses profissionais: talvez seja a hora de escutar o que eles têm a dizer sobre suas expectativas e repensar as formas de realizar as atividades e tomar decisões, de modo a atrair, reter e potencializar a contribuição desses jovens para as organizações.

Por outro lado, é possível que ainda não esteja claro para muitos "Ys" que, embora o conhecimento técnico, relacionado à formação profissional, possa ser aprendido mais rapidamente, outras habilidades, entre elas as chamadas soft skills - como saber se comunicar e ouvir, relacionar-se bem com pessoas, trabalhar em equipe, lidar com a complexidade, entre outras características demandam mais tempo, experiência e vivência para ser absorvidas, e é muito difícil "queimar etapas" nesse aprendizado. 